\title{
Effect of 3-year folic acid supplementation on cognitive function in older adults in the FACIT trial: a randomised, double blind, controlled trial
}

Citation for published version (APA):

Durga, J., van Boxtel, M. P. J., Schouten, E. G. W., Kok, F. J., Jolles, J., Katan, M. B., \& Verhoef, P. (2007). Effect of 3-year folic acid supplementation on cognitive function in older adults in the FACIT trial: a randomised, double blind, controlled trial. Lancet, 369(9557), 208-216. https://doi.org/10.1016/S01406736(07)60109-3

Document status and date:

Published: 01/01/2007

DOI:

10.1016/S0140-6736(07)60109-3

Please check the document version of this publication:

- A submitted manuscript is the version of the article upon submission and before peer-review. There can be important differences between the submitted version and the official published version of record.

People interested in the research are advised to contact the author for the final version of the publication, or visit the DOI to the publisher's website.

- The final author version and the galley proof are versions of the publication after peer review.

- The final published version features the final layout of the paper including the volume, issue and page numbers.

Link to publication

\footnotetext{
General rights rights.

- You may freely distribute the URL identifying the publication in the public portal. please follow below link for the End User Agreement:

www.umlib.nl/taverne-license

Take down policy

If you believe that this document breaches copyright please contact us at:

repository@maastrichtuniversity.nl

providing details and we will investigate your claim.
}

Copyright and moral rights for the publications made accessible in the public portal are retained by the authors and/or other copyright owners and it is a condition of accessing publications that users recognise and abide by the legal requirements associated with these

- Users may download and print one copy of any publication from the public portal for the purpose of private study or research.

- You may not further distribute the material or use it for any profit-making activity or commercial gain

If the publication is distributed under the terms of Article $25 \mathrm{fa}$ of the Dutch Copyright Act, indicated by the "Taverne" license above, 


\title{
Effect of 3-year folic acid supplementation on cognitive function in older adults in the FACIT trial: a randomised, double blind, controlled trial
}

\author{
Jane Durga, Martin P J van Boxtel, Evert G Schouten, Frans J Kok, Jelle Jolles, Martijn B Katan, Petra Verhoef
}

Summary

Lancet 2007; 369: 208-16 See Comment page 166 Division of Human Nutrition, Wageningen University, 6700 EV Wageningen, Netherlands (J Durga PhD, Prof E G Schouten PhD, Prof FJ Kok PhD, P Verhoef PhD); Wageningen Centre for Food Sciences, Wageningen, Netherlands (J Durga,

M B Katan PhD, P Verhoef) Department of Psychiatry and Neuropsychology, Brain and Behaviour Institute, Maastricht University, Maastricht, Netherlands (M P ) van Boxtel PhD, Prof J Jolles PhD)

Correspondence to: Dr Jane Durga, Nestlé Research Centre, Nutrition and Health Department, Vers Chez les Blanc 1000 Lausanne 26, Switzerland jane.durga@rdls.nestle.com

Background Low folate and raised homocysteine concentrations in blood are associated with poor cognitive performance in the general population. As part of the FACIT trial to assess the effect of folic acid on markers of atherosclerosis in men and women aged 50-70 years with raised plasma total homocysteine and normal serum vitamin $B_{12}$ at screening, we report here the findings for the secondary endpoint: the effect of folic acid supplementation on cognitive performance.

Methods Our randomised, double blind, placebo controlled study took place between November, 1999, and December, 2004, in the Netherlands. We randomly assigned 818 participants $800 \mu \mathrm{g}$ daily oral folic acid or placebo for 3 years. The effect on cognitive performance was measured as the difference between the two groups in the 3-year change in performance for memory, sensorimotor speed, complex speed, information processing speed, and word fluency. Analysis was by intention-to-treat. This trial is registered with clinicaltrials.gov with trial number NCT00110604.

Findings Serum folate concentrations increased by 576\% (95\% CI 539 to 614) and plasma total homocysteine concentrations decreased by $26 \%$ (24 to 28 ) in participants taking folic acid compared with those taking placebo. The 3-year change in memory (difference in Z scores 0.132 , 95\% CI 0.032 to $\mathbf{0 . 2 3 3}$ ), information processing speed $(0.087,0.016$ to 0.158$)$ and sensorimotor speed $(0.064,-0.001$ to 0.129$)$ were significantly better in the folic acid group than in the placebo group.

Interpretation Folic acid supplementation for 3 years significantly improved domains of cognitive function that tend to decline with age.

\section{Introduction}

Cognitive function declines with ageing, especially cognitive domains related to memory and information processing speed. ${ }^{1}$ Changes in cognitive performance, especially memory function, have been linked to risk of dementia in old age., ${ }^{2,3}$ Modifiable risk factors for agerelated cognitive decline have been identified, but their causality has not yet been established. ${ }^{4}$ Poor folate status is one such suspected risk factor. ${ }^{5,6}$

A longitudinal study, ${ }^{7}$ undertaken in the USA when folic acid fortification of foods was routine, showed greater cognitive decline in people with a high folic acid intake than in those with low intakes. A systematic review of supplementation with folic acid alone or in combination with other $\mathrm{B}$ vitamins showed that no beneficial effect on cognitive performance was conferred. ${ }^{8}$ Many of the trials have used small study populations, supplemented for a short duration, or used tests such as the Mini-Mental State Examination, ${ }^{9}$ which are unable to detect subtle changes in cognitive function (table 1). ${ }^{10-19}$

We investigated whether $800 \mu \mathrm{g}$ daily oral folic acid supplementation for 3 years improved cognitive performance compared with placebo in older adults. Cognitive performance was assessed with tests that probe cognitive domains that decline in the ageing process.

\section{Methods}

Participants

Participants were men and post-menopausal women aged $50-70$ years, from the Gelderland region in the Netherlands who participated in the Folic Acid and Carotid Intimamedia Thickness (FACIT) trial (unpublished), a study investigating the effect of folic acid supplementation on atherosclerotic progression. Additional outcomes of the trial were age-related decline in cognitive function and hearing. Here we present data for the effect of folic acid on the cognitive performance aspect of the study.

We used municipal and blood-bank registries to recruit participants. On the assumption that high concentrations of plasma total homocysteine were a risk factor for vascular disease, we selected participants expected to benefit from folic acid's homocysteine-lowering effect and excluded participants with concentrations of plasma total homocysteine of less than $13 \mu \mathrm{mol} / \mathrm{L}$ (73\% of those screened). We excluded participants with raised homocysteine concentrations (>26 $\mu \mathrm{mol} / \mathrm{L})$ that were possibly due to factors other than suboptimal folate concentrations, including: serum vitamin $\mathrm{B}_{12}$ concentration of less than $200 \mathrm{pmol} / \mathrm{L}$ (10\% of those screened); selfreported medical diagnosis of renal or thyroid disease; or self-reported use of medications that influence folate metabolism..$^{20}$ Additionally, we excluded participants with self-reported intestinal disease and participants who 
reportedly used B-vitamin supplements or drugs that could affect atherosclerotic progression. Finally, more than $80 \%$ self-reported compliance during a 6-week placebo run-in period was required. The Wageningen University medical ethics committee approved the study and participants gave written informed consent.

\section{Procedures}

After the initial measurement sessions, participants were allocated placebo or $800 \mu \mathrm{g}$ per day folic acid, which is regarded as a low dose for a clinical trial. Patients were allocated treatment or placebo with permuted blocks of sizes four and six, which varied randomly. Specialised staff who were not involved in the study allocated and labelled the capsule boxes with participants' unique sequence number. Participants in the same household received the same treatment. The folic acid and placebo capsules, produced by Swiss-Caps Benelux (Heerhugowaard, Netherlands), were indistinguishable in appearance. Capsules were individually packaged in foil strips containing 28 capsules per strip, with the days of the week printed on the back. Every year, participants received a 13-month supply of capsules. Compliance was judged by capsule-return counts and a diary that registered missed capsules. Diaries and capsules were returned by participants every 12 weeks.

At the end of the study, the proportion of participants who thought they had received folic acid or placebo did not differ between the two groups $(\mathrm{p}=0 \cdot 64) .70 \%$ of participants in the folic acid group and $71 \%$ in the placebo group thought they had been allocated folic acid; whereas $11 \%$ in the folic acid group and $9 \%$ in the placebo group thought

\begin{tabular}{|c|c|c|c|c|c|c|c|}
\hline & Duration & $\begin{array}{l}\text { Number at } \\
\text { follow-up } \\
\text { (in } \\
\text { analyses) }\end{array}$ & $\begin{array}{l}\text { Mean } \\
\text { age, } \\
\text { years, } \\
\text { SD) }\end{array}$ & Population type & $\begin{array}{l}\text { Dose of folic } \\
\text { acid (dose of } \\
\text { placebo), } \\
\text { mg per day }\end{array}$ & Types of cognitive test & Conclusion \\
\hline \multicolumn{8}{|l|}{ Folic acid only } \\
\hline $\begin{array}{l}\text { Fioravanti } \\
\text { et } \mathrm{al}^{10}\end{array}$ & 60 days & 29 & $80(6)$ & $\begin{array}{l}\text { Patients with memory complaints, } \\
\text { Mini-Mental State Examination } \\
\text { score between } 16 \text { and } 24 \text {, mild to } \\
\text { moderate cognitive decline on basis } \\
\text { of Global Deterioration Score, } \\
70-90 \text { years, serum folate }<7 \mathrm{nmol} / \mathrm{L}\end{array}$ & 15 & $\begin{array}{l}1 \text { Randt Memory Test } \\
\text { a Acquistion and recall } \\
\text { b Delayed recall } \\
\text { c Memory index } \\
\text { d Encoding factor } \\
\text { e Cognitive efficiency } \\
\text { f Attention efficiency }\end{array}$ & $\begin{array}{l}\text { Folic acid improved attention efficiency } \\
\text { score }(p<0.05) \text {. } \\
\text { When taking into account baseline folate } \\
\text { status, folic acid improved acquisition and } \\
\text { recall }(p<0.007) \text {, delayed recall ( }<<0.007) \text {, } \\
\text { memory index ( } p<0.002) \text {, encoding } \\
(p<0.005) \text {. }\end{array}$ \\
\hline Sommer et $\mathrm{a}^{11}$ & 10 weeks & 7 & $77(4)$ & $\begin{array}{l}\text { Patients meeting DSM-III-R criteria } \\
\text { for dementia, } \geq 65 \text { years, } \\
\text { suboptimal folate (serum folate } \\
2-5 \mathrm{ng} / \mathrm{mL} \text {, red-blood-cell } \\
\text { folate } 127-452 \mathrm{ng} / \mathrm{mL} \text { ), } \\
\text { B12 }>200 \mathrm{pg} / \mathrm{mL}\end{array}$ & $2 \times 10$ & $\begin{array}{l}1 \text { Wechsler Memory Scale } \\
\text { 1a Logical memory subtest } \\
1 \text { b Associate learning subtest } \\
2 \text { Boston Naming test } \\
3 \text { Controlled Oral Word Association test } \\
4 \text { Trail making test } \\
5 \text { Finger Tapping test } \\
6 \text { Wechsler Adult Intelligence Scale- } \\
\text { revised (composite of information, } \\
\text { vocabulary and similarities sub-tests) } \\
7 \text { Benton Visual Retention test }\end{array}$ & $\begin{array}{l}\text { Folic acid seemed to reduce performance on } \\
\text { associate learning subtest of Wechsler } \\
\text { Memory Scale }(p=0.08) \text { and Trails B } \\
(p=0.08)\end{array}$ \\
\hline \multicolumn{8}{|c|}{ Folic acid with other B vitamins } \\
\hline Eussen et $\mathrm{a}^{12}$ & 24 weeks & 162 & $82(5)$ & $\begin{array}{l}\text { Mini-Mental State Examination } \geq \\
19, \geq 70 \text { years, suboptimal vitamin } \\
\text { B12 status (B12 100-200 pmol/L or } \\
\text { B12 200-300 pmol/L, } \\
\text { methylmalonic acid } \geq 0 \cdot 32 \mu \mathrm{mol} / \mathrm{L} \text {, } \\
\text { creatinine } \leq 120 \mu \mathrm{mol} / \mathrm{L} \text { ) }\end{array}$ & 0.4 & $\begin{array}{l}\text { Domains based on clustering of similar } \\
\text { tests } \\
1 \text { Attention } \\
2 \text { Construction } \\
3 \text { Sensomotor speed } \\
4 \text { Memory } \\
5 \text { Executive function }\end{array}$ & $\begin{array}{l}\text { Compared with placebo or to vitamin } B_{12} \\
\text { only. No effect of folic acid on cognitive } \\
\text { domains. }\end{array}$ \\
\hline McMahon et $\mathrm{a}^{13}$ & 2 years & 253 & $74(6)$ & $\begin{array}{l}\geq 65 \text { years, homocysteine } \\
\geq 13 \mu \mathrm{mol} / \mathrm{L}\end{array}$ & 1 & $\begin{array}{l}1 \text { Mini-Mental State Examination } \\
2 \text { Wechsler Paragraph Recall } \\
3 \text { Category Word Fluency } \\
4 \text { Rey Auditory Verbal Learning } \\
4 \text { a composite of trials 1-5 } \\
4 \text { b trial } 7 \\
5 \text { Raven's Progressive Matrices } \\
6 \text { Controlled Oral Word Association } \\
7 \text { Reitan Trail Making, part B } \\
8 \text { Composite score of all tests }\end{array}$ & $\begin{array}{l}\text { General trend towards reduced performance } \\
\text { on tests. In crude analyses significance was } \\
\text { reached for the Reitan Trail Making test part } \\
\text { B) ( } 7 \% \text { slower, } 95 \% \mathrm{Cl} 2 \text { to } 13 \%) \text { and Wechsler } \\
\text { Paragraph Recall test (mean difference }-1 \cdot 19 \text {, } \\
95 \% \mathrm{Cl}-2 \cdot 30 \text { to }-0.04) \text {. } \\
\text { After adjustment for baseline performance, } \\
\text { sex, and education, the composite score of } \\
\text { all tests was lower in the folic acid group } \\
\text { than in the placebo group }(-0.11,95 \% \mathrm{Cl} \\
-0.22 \text { to } 0 \cdot 00) \text {. }\end{array}$ \\
\hline Stott et al ${ }^{14}$ & 1 year & 167 & $75(6)$ & $\begin{array}{l}\text { Mini-Mental State Examination } \geq \\
19 \text {, ischaemic vascular disease, } \\
\geq 65 \text { years, red-blood-cell folate } \\
\geq 280 \mathrm{ng} / \mathrm{mL} \text {, vitamin B12 } \\
\geq 250 \mathrm{pg} / \mathrm{mL}\end{array}$ & $2 \cdot 5$ & $\begin{array}{l}1 \text { Telephone Interview for Cognitive } \\
\text { Status } \\
2 \text { Letter Digit Coding }\end{array}$ & No effect \\
\hline
\end{tabular}




\begin{tabular}{|c|c|c|c|c|c|c|c|}
\hline \multicolumn{8}{|c|}{ (Continued from previous page) } \\
\hline Bryan et al ${ }^{15}$ & 5 weeks & 104 & $51(20)$ & Healthy women & $0 \cdot 75$ & $\begin{array}{l}1 \text { Boxes test } \\
2 \text { Digit Symbol Coding, } 120 \mathrm{~s} \\
3 \text { Symbol search } \\
4 \text { Digit Span Backward } \\
5 \text { Letter-Number Sequencing } \\
6 \text { Rey Auditory-Verbal Learning test } \\
6 \text { a Immediate recall } \\
6 \text { b Delayed recall } \\
7 \text { Digit Symbol Coding, symbol recall } \\
8 \text { Activity recall } \\
9 \text { Stroop test } \\
10 \text { Self-ordered pointing task } \\
11 \text { Uses for common objects } \\
12 \text { Trail Making test } \\
13 \text { Verbal Fluency test } \\
14 \text { Excluded Letter Fluency } \\
15 \text { Wechsler Adult Intelligence Scale - } \\
\text { III Vocabulary } \\
16 \text { Spot-the-Word test }\end{array}$ & $\begin{array}{l}\text { Folic acid reduced Verbal Fluency } \\
\text { performance }(p<0.05) \text {. } \\
\text { When stratifying by age, folic acid improved } \\
\text { Rey Auditory-Verbal Learning test } \\
\text { (recognition task) in older participants } \\
\text { (>65 years, } p<0.05) \text {. }\end{array}$ \\
\hline Toole et $\mathrm{al}^{16}$ & 2 years & 3097 & $66(10)$ & $\begin{array}{l}\text { Previous stroke, homocysteine } \\
>\sim 9 \mu \mathrm{mol} / \mathrm{L}\end{array}$ & 2.5 or 0.02 & 1 Mini-Mental State Examination & No effect \\
\hline $\begin{array}{l}\text { Vital Trial } \\
\text { Collaborative } \\
\text { Group }^{17}\end{array}$ & 12 weeks & 128 & $\begin{array}{l}\text { Range } \\
56 \cdot 89\end{array}$ & $\begin{array}{l}\text { Mini-Mental State Examination } \\
\text { score } 12-26 \text { or mild cognitive } \\
\text { impairment assessed by } \\
\text { modified Telephone Interview } \\
\text { of Cognitive Status }\end{array}$ & 2 & $\begin{array}{l}1 \text { Mini-Mental State Examination } \\
2 \text { Alzheimer's Disease Assessment Scale } \\
\text { (cognitive part) }\end{array}$ & No effect \\
\hline Lewerin et $\mathrm{al}^{18}$ & 4 months & $171-179$ & $76(4)$ & Community-dwelling & 0.8 & $\begin{array}{l}1 \text { Digit Span Forward } \\
2 \text { Digit Span Backward } \\
3 \text { Identical forms } \\
4 \text { Visual reproduction } \\
5 \text { Synonyms } \\
6 \text { Block design } \\
7 \text { Digit Symbol, 90s } \\
8 \text { Thurstone's Picture Memory test } \\
9 \text { Figure Classification }\end{array}$ & $\begin{array}{l}\text { Folic acid improved performance on identical } \\
\text { forms and synonyms }(p<0 \cdot 05) \text {. }\end{array}$ \\
\hline Obeid et a $\left.\right|^{19}$ & 45 days & 69 & $80(6)$ & $\begin{array}{l}\text { Mini-Mental State Examination } \\
\text { score }>15,>65 \text { years }\end{array}$ & $\begin{array}{l}5 \cdot 0 \text { orally or } 1 \cdot 1 \\
\text { (intravenously } \\
\text { three times a } \\
\text { week for } \\
3 \text { weeks) }\end{array}$ & $\begin{array}{l}1 \text { Structured Interview for Diagnosis of } \\
\text { Dementia of Alzheimer Type, Multi- } \\
\text { infarct Dementia and Dementia } \\
2 \text { Orientation abilities } \\
3 \text { Memory } \\
4 \text { Intellectual abilities }\end{array}$ & $\begin{array}{l}\text { No treatment effect reported, only } \\
\text { differences in performance within groups }\end{array}$ \\
\hline
\end{tabular}

DSM-III-R=Diagnostic and Statistical manual of Mental Disorders, 3rd edition revised.

Table 1: Summary of randomised controlled trials examining effect of folic-acid-containing supplements on cognitive function

they had been allocated placebo. All staff, including all authors, were unaware of group assignment until completion of the trial and after data analyses.

We assessed cognitive function using five separate tests used in the Maastricht Aging Study. ${ }^{21}$ These five tests were used to construct five a-priori-defined cognitive domains: memory, sensorimotor speed, complex speed, information processing speed, and word fluency. ${ }^{22}$ Descriptions of the tests are in panel $1{ }^{23-27}$ Although not part of the cognitive tests used for our study outcome, we used the Mini-Mental State Examination ${ }^{9}$ to screen for participants with possible dementia, defined as a score of less than 24 points.

All participants underwent the measurements after an overnight fast, followed by a glass of fruit juice and a bread product for breakfast. Two trained research assistants oversaw the tests during a 40-min session; they used standard wording to instruct participants. A third research assistant periodically observed the testing to ensure that the two research assistants did not deviate from the protocol. All cognitive tests were done in the same room with the same props. We repeated cognitive testing at the end of the study using variations of the tests used at baseline (parallel versions). We repeated the verbal fluency test because the validity of a parallel version of the animalnaming part of the test has not been established.

Fasting venous blood was processed and samples were stored at $-80^{\circ} \mathrm{C}$. We measured serum folate, erythrocyte folate, serum vitamin $B_{12}$, plasma total homocysteine, plasma vitamin $\mathrm{B}_{6}$, serum creatinine, and lipids as described elsewhere. ${ }^{22}$ The C677T polymorphism in the gene encoding methylenetrahydrofolate reductase $(M T H F R)^{28}$ and apolipoprotein E genotype were determined by PCR of DNA and restriction digestion with HinFl and Hha1, respectively.

Self-reported medical history, including current drug use and smoking habits, were ascertained by questionnaire 
and reviewed by a research assistant with the participant. Education was grouped according to highest attained level. ${ }^{29}$ Height and weight were measured and body-mass index calculated. Blood pressure was measured with an automated meter (Dinamap Compact Pro 100, General Electric). Eight blood-pressure measurements were taken and the average calculated. We used a food-frequency questionnaire to estimate dietary folate intake during the past 3 months.

We measured genotype and attained educational level at the beginning of the study. Plasma total homocysteine, serum folate, and vitamin $B_{12}$ concentrations and information about medical status and drug use were recorded yearly and all other measurements were taken at the beginning and end of the study.

\section{Statistical analyses}

Our sample size calculation was based on the mean intimamedia thickness progression of the common carotid artery (the primary endpoint of the FACIT trial). We assumed that if the progression of the mean carotid intima-media were $0.01 \mathrm{~mm}$ (SD $0.06 \mathrm{~mm}$ ), then 251 participants would be needed in each group to detect a difference of $0.015 \mathrm{~mm}$ (power 80\%, two-sided $\alpha=0 \cdot 05$ ). We assumed that 30-40\% of the population could be lost to follow-up.

The cognitive domains were constructed with $Z$ scores (panel 2). ${ }^{21}$ Sensorimotor speed measures basic speed, and shows direct stimulus-response connections with little central processing, whereas complex speed measures time needed for higher-order information processing. As other investigators have done, ${ }^{30,31}$ we present global cognitive function (an average of the domains). The test scores at the beginning and end of the study were pooled to calculate the grand mean and SD per test; this information was used to calculate the $Z$ scores (panel 2). At baseline, one participant missed $50 \%$ or more of the subtests for complex speed and three participants did not have an information processing speed score. These participants were assigned the median score of these domains of the total population at baseline. 17 participants lost to followup were assigned the median test score of the total population at the end of the study. Analyses were done on an intention-to-treat basis with SPSS 11.0. No adjustments were made for multiple testing.

The outcome of this study was the difference between the folic acid and placebo groups in the 3-year change in performance for memory, sensorimotor speed, complex speed, information-processing speed, and word fluency.

\section{Panel 1: Description of cognitive function tests}

\section{Word learning test ${ }^{23}$}

Measures the storage and retrieval of newly acquired verbal information. Participants were instructed to memorise 15 commonly used monosyllabic words. The words were printed on a card and were presented in a fixed sequence for $2 \mathrm{~s}$. Immediately after the 15 words are presented, the participants are asked to recall the words. This procedure was done three times. 20 min after presentation of the words, participants were prompted to recall the 15 words. The maximum and total number of correctly repeated words of the immediate recall tests were recorded, as well as the number of correctly repeated words in the delayed recall test.

\section{Concept shifting test ${ }^{24}$}

A timed test with four subtests that measure the ease of switching between two psychological concepts. Each subtest was printed on one sheet of paper, which contained 16 circles (15 mm diameter) arranged in a larger circle $(16 \mathrm{~cm}$ diameter). For the first subtest, participants were asked to cross off the circles in numerical and alphabetical order (eg, 1, A, 2, B, 3, C, etc).

\section{Stroop colour-word test ${ }^{25}$}

Measures selective attention and susceptibility to behavioural interference and consists of three subtests. Each subtest was presented on a separate sheet containing four rows of ten columns of colour names of coloured blocks. For the first subtest, participants were instructed to read words printed in black ink (words were "red", "blue", "green", and "yellow").

Participants were asked to name coloured blocks in the second subtest, for the final subtest, participants were asked to name the colour of the ink, rather than read the word (eg, say blue when the word "RED" was printed in blue ink).

\section{Verbal fluency test ${ }^{26}$}

Measures word fluency or the ability to draw on one's encyclopaedic memory in a strategic manner. Participants were asked to name as many animals as possible in $1 \mathrm{~min}$. This test indicated the amount of organisation among clusters of related words (eg, pets, zoo animals, etc).

\section{Letter digit substitution test ${ }^{27}$}

Assesses general speed of visual information processing. Nine different letters were assigned a unique number (1-9) in a key at the top of the form. The participants were presented with a random series of letters in cells and were instructed to add the corresponding digit to the letters. The number of correctly copied corresponding digits in $90 \mathrm{~s}$ was recorded.

We used the $t$ test to determine whether the change in cognitive performance differed between treatment groups. We did all analyses without knowledge of followup folate or homocysteine concentrations. The treatment code was broken once an independent statistician had verified the data and all authors had formally approved the tables showing the main effects.

In secondary analyses, we determined whether the effect of folic acid supplementation was dependent on initial concentrations of folate or homocysteine or MTHFR C677T genotype. We determined the effect of folic acid

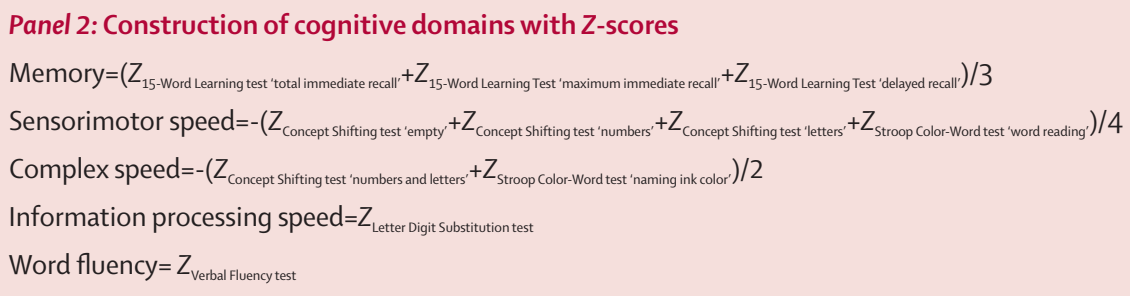




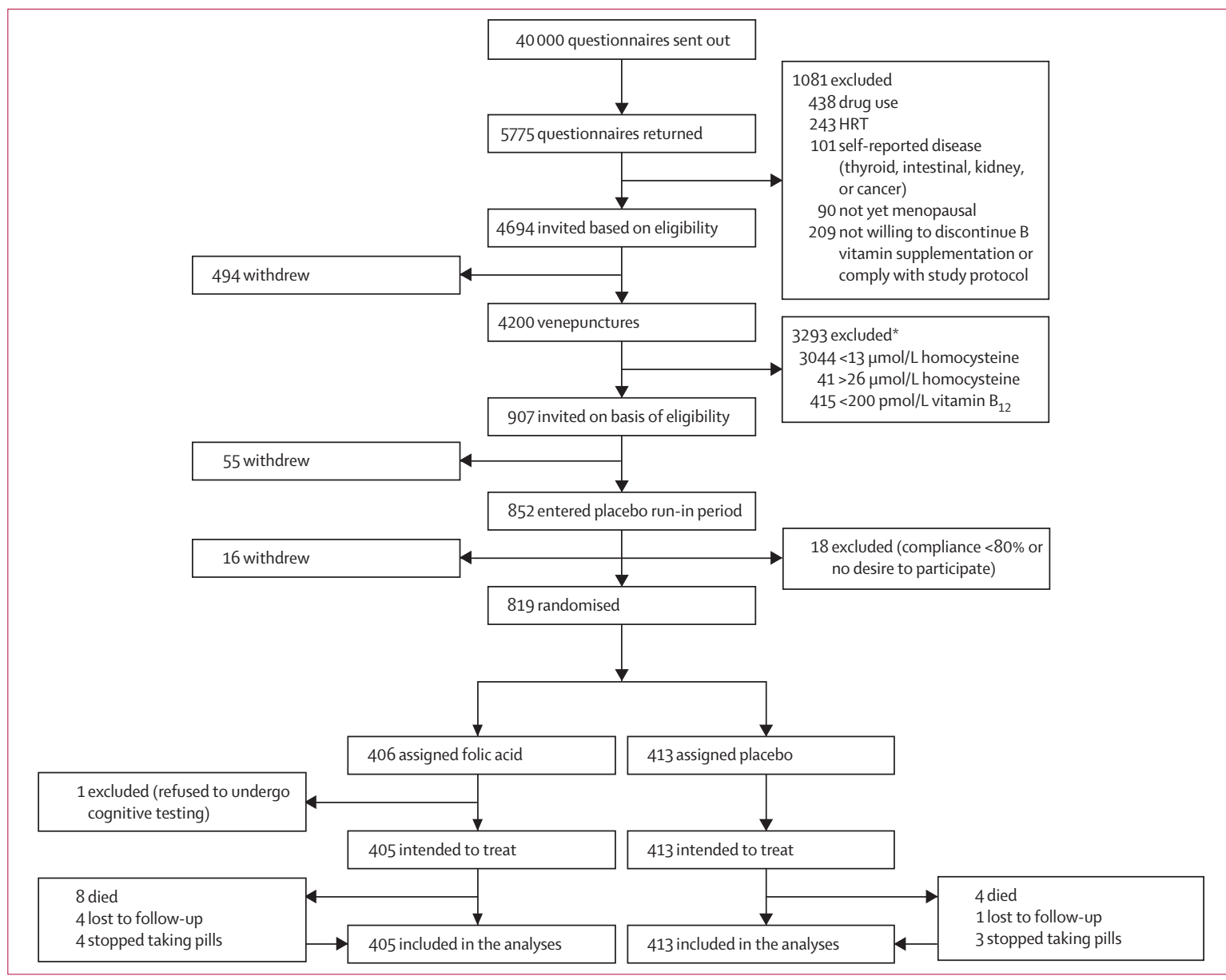

Figure: Trial profile

HRT=hormone replacement therapy. *Participants might have been excluded for multiple reasons.

supplementation per stratum (median cut-off) using an independent sample $t$ test. We used linear regression models to examine whether the difference in treatment effects between strata was significant.

\section{Role of the funding source}

The sponsors had no role in the design or implementation of the study, data collection, data management, data analysis, data interpretation, or in the preparation, review, or approval of the manuscript. The corresponding author had full access to all the data in the study and had final responsibility for the decision to submit for publication.

\section{Results}

Patients were randomised between November, 1999, and April, 2001, and the study was undertaken from September, 2000 , to December, 2004. The figure shows the trial profile. Five participants allocated folic acid treatment reported adverse events: forgetfulness, sun allergies, weight gain, tinnitus, and dark urine. Adverse effects reported in the placebo group ( $n=7)$ were muscle aches, headaches, weight gain, queasiness, bitter taste in mouth, and skin irritations.
The participant with headache complaints dropped out of the trial prematurely. 17 participants $(2 \%)$ did not return for the cognitive function measurements after 3 years, and six participants stopped treatment prematurely. The proportion of participants lost to follow-up or who stopped treatment early did not differ between the groups $(\mathrm{p}=0 \cdot 25)$. Apart from these participants, the compliance of the participants was high, with $99 \%$ of the capsules reportedly consumed. Table 2 shows baseline clinical characteristics of the participants.

In both groups, plasma total homocysteine concentrations at baseline were lower than at screening, a likely result of regression to the mean (table 3). After 3 years, serum folate concentrations were significantly higher in the folic acid group than in the placebo group (table 3 ).

Baseline scores on the cognitive tests and domains were similar between the two groups (table 4). At baseline, one participant in the folic acid group and six in the placebo group scored less than 24 points on the Mini-Mental State Examination $(\mathrm{p}=0 \cdot 85)$. Whereas sensorimotor speed, information-processing speed, and complex speed declined significantly during the 3-year study in the placebo group, 
the rate of decline was slower in these domains in the folic acid group (table 5). Both groups improved on memory tests, because of procedural learning effects. However, the improvement was significantly greater in the folic acid group than in the placebo group.

The 3-year change in cognitive function was significantly better in the folic acid group than in the placebo group in terms of information-processing speed. Folic acid did not affect sensorimotor speed, complex speed, or word fluency. Global cognitive function, defined as the average of the five domains, improved significantly (table 5). Performance on the Mini-Mental State Examination was not affected by folic acid group $(p=0 \cdot 63)$. The median score for both groups after 3 years was 29 points (IQR 28-30) ranging from 21 to 30 points in the folic acid and 16 to 30 points in the placebo group.

In addition to memory and information-processing speed, sensorimotor speed improved significantly $(\mathrm{p}<0 \cdot 05)$ when other imputation techniques were used (eg, last value carried forward, expectation maximisation), when 17 participants lost to follow-up were excluded from the analyses, and when seven participants with initial MiniMental State Examination scores of less than 24 points were excluded from the analyses. Finally, at baseline, a greater proportion of participants with a low educational level, an important determinant of cognitive performance, were randomised into the folic acid group. Additionally, a higher proportion of participants in the folic acid group had dyslipidaemia and self-reported vascular disease. Our results did not change when we adjusted for these variables.

51 participants received the same treatment and lived in the same households. Hence these observations were not independent of one another. When partners were excluded from the analyses, the results did not change, except that folic acid supplementation significantly improved sensorimotor speed (difference in Z scores 0 079 [95\% CI $0 \cdot 014-0 \cdot 145])$.

To show the relevance of our findings we compared the regression coefficient of age-adjusted for sex, education, and treatment calculated with linear regression models with initial performance as the dependent variable-with the treatment effect. 3-year folic acid supplementation confers an individual the performance of someone $4 \cdot 7$ years younger for memory ( $95 \%$ CI $1 \cdot 1-8 \cdot 3), 1 \cdot 7$ years younger for sensorimotor speed $(-0 \cdot 04$ to $3 \cdot 4), 2 \cdot 1$ years younger for information processing speed $(0 \cdot 4-3 \cdot 7)$, and $1 \cdot 5$ years younger for global cognitive function $(0 \cdot 1-2 \cdot 8)$. Of our test battery, memory-specifically delayed memory-is the most clinically relevant test. We showed that 3-year folic acid supplementation improved performance on the delayed recall sub-test of the 15 word learning test by $0 \cdot 47$ words $(95 \%$ CI $0 \cdot 14-0 \cdot 79, \mathrm{p}=0 \cdot 005)$. This improvement is similar to a performance of an individual $6 \cdot 9$ years younger $(95 \%$ CI $2 \cdot 1-11 \cdot 8)$.

The effect of folic acid supplementation was not modified by initial folate status or MTHFR C677T genotype.

\begin{tabular}{|c|c|c|}
\hline & Folic acid ( $n=405)$ & Placebo $(n=413)$ \\
\hline Age (years) & $60(5)$ & $60(6)$ \\
\hline Male & $294(72 \%)$ & $292(70 \%)$ \\
\hline High / middle / low education & $154(38 \%) / 144(36 \%) / 107(26 \%)$ & $169(41 \%) / 168(41 \%) / 76(18 \%)$ \\
\hline Mini-mental state examination (points) & $29(28-30)$ & $29(28-30)$ \\
\hline Range (points) & $18-30$ & $15-30$ \\
\hline MTHFR 677T allele $0,1,2^{*}$ & $143(36 \%), 187(46 \%), 73(18 \%)$ & $168(41 \%), 191(46 \%), 52(13 \%)$ \\
\hline Vitamin $B_{12}(p m o l / L)$ & $290(239-366)$ & $286(247-363)$ \\
\hline Vitamin $\mathrm{B}_{6}(\mathrm{nmol} / \mathrm{L}) \dagger$ & $37 \cdot 8(28 \cdot 2-49 \cdot 8)$ & $368 \cdot 4(28 \cdot 2-48 \cdot 3)$ \\
\hline Creatinine (mmol/L) & $92.7(12.5)$ & $92 \cdot 4(12 \cdot 0)$ \\
\hline Total cholesterol (mmol/L) & $5 \cdot 8(1 \cdot 1)$ & $5 \cdot 8(1 \cdot 1)$ \\
\hline LDL cholesterol $(\mathrm{mmol} / \mathrm{L}) \dagger$ & $4 \cdot 0(1 \cdot 0)$ & $4 \cdot 0(1 \cdot 0)$ \\
\hline HDL cholesterol (mmol/L) & $1.2(0 \cdot 3)$ & $1.2(0.4)$ \\
\hline Dyslipidaemia $\ddagger$ & $156(39 \%)$ & $138(33 \%)$ \\
\hline ApoE \& 4 allele, $0,1,25$ & $271(67 \%), 122(30 \%), 11(3 \%)$ & $282(69 \%), 116(28 \%), 12(3 \%)$ \\
\hline Systolic blood pressure $(\mathrm{mm} \mathrm{Hg})^{*}$ & $133(16)$ & $133(16)$ \\
\hline Diastolic blood pressure $(\mathrm{mm} \mathrm{Hg})^{*}$ & $77(8)$ & $77(9)$ \\
\hline Hypertension* & $94(23 \%)$ & $88(21 \%)$ \\
\hline Body-mass index $\|$ & $26 \cdot 6(3 \cdot 6)$ & $26 \cdot 5(3 \cdot 6)$ \\
\hline Current smokers & $84(21 \%)$ & $83(20 \%)$ \\
\hline Diabetes mellitus & $12(3 \%)$ & $14(3 \%)$ \\
\hline Self-reported cardiovascular disease ${ }^{* *}$ & $58(14 \%)$ & $39(9 \%)$ \\
\hline \multicolumn{3}{|c|}{$\begin{array}{l}\text { MTHFR=methylenetetrahyrdofolate reductase. *Data available for } 403 \text { participants in folic acid group and } \\
411 \text { participants in placebo group. †Data available for } 411 \text { participants in placebo group. } \neq \text { Total cholesterol } \\
>6.5 \mathrm{mmol} / \mathrm{L}, \mathrm{HDL} \text { cholesterol }<0.9 \mathrm{mmol} / \mathrm{L} \text { or use of lipid-lowering drugs. SData available for } 403 \text { participants in folic } \\
\text { acid group and } 410 \text { participants in placebo group. } \uparrow \text { Systolic blood pressure } \geq 160 \mathrm{~mm} \mathrm{Hg} \text {, diastolic blood pressure } \\
\geq 95 \mathrm{~mm} \mathrm{Hg} \text { or use of antihypertensive drugs. ||body-mass index=weight in } \mathrm{kg} \text { divided by the square of the height in } \\
\text { metres. **Diagnosis of angina pectoris, myocardial infarction, arrhythmia, stroke, or peripheral arterial disease, or } \\
\text { having undergone angioplasty, coronary bypass surgery, or aortic aneurysm surgery. Data are mean (SD), median (IQR) } \\
\text { or number (\%) unless otherwise indicated. }\end{array}$} \\
\hline
\end{tabular}

Compared with placebo, participants with initial plasma total homocysteine concentrations greater than the population median of $12.9 \mu \mathrm{mol} / \mathrm{L}$ showed a greater improvement in information processing speed than participants with concentrations lower than the population median (interaction term $\mathrm{p}=0 \cdot 034$ ). Informationprocessing speed of the latter group improved by $0 \cdot 013$, (95\% CI -0.086 to $0 \cdot 111$ ), whereas participants with higher homocysteine concentrations improved by 0.166 , $(0 \cdot 064-0 \cdot 267)$. Outcomes of the other four domains and global cognitive function were not affected by initial plasma total homocysteine concentrations.

In post-hoc analyses, we examined whether low concentrations of vitamin B12 modified the effect of folic acid supplementation on cognitive performance. Folic acid supplementation improved sensorimotor speed (difference in $Z$ score $0 \cdot 112$, 95\% CI $0 \cdot 001-0 \cdot 223$ ) and information processing speed $(0 \cdot 190,0 \cdot 055-0 \cdot 325)$ in 230 participants with initial low or normal concentrations of vitamin $\mathrm{B}_{12}(<250 \mathrm{pmol} / \mathrm{L})$, but not in 588 participants with vitamin $B_{12}$ concentrations of $250 \mathrm{pmol} / \mathrm{L}$ or greater $(0.046,-0.033$ to 0.126 and $0.048,-0.036$ to 0.131 , respectively). 


\begin{tabular}{|c|c|c|c|}
\hline & Folic acid & Placebo & $\mathrm{p}$ \\
\hline \multicolumn{4}{|c|}{ Serum folate (nmol/L)* } \\
\hline Baseline & $12(9-15)$ & $12(10-15)$ & .. \\
\hline Year 1 & $53(44-86)$ & $12(9-15)$ & $<0.001$ \\
\hline Year 2 & $50(42-85)$ & $12(9-15)$ & $<0.001$ \\
\hline Year 3 & $76(50-103)$ & $13(10-17)$ & $<0.001$ \\
\hline \multicolumn{4}{|c|}{ Erythrocyte folate (nmol/L) $\dagger$} \\
\hline Baseline & $630(494-829)$ & $671(535-815)$ & .. \\
\hline Year 3 & $2043(1741-2469)$ & $697(546 \cdot 1-888)$ & $<0.001$ \\
\hline \multicolumn{4}{|c|}{ Dietary folate intake ( $\mu$ g per day) $\ddagger$} \\
\hline Baseline & $192(159-238)$ & $195(158-242)$ & .. \\
\hline Year 3 & $182(152-218)$ & $179(152-224)$ & 0.946 \\
\hline \multicolumn{4}{|c|}{ Plasma total homocysteine $(\mu \mathrm{mol} / \mathrm{L}) \S$} \\
\hline Baseline & $13 \cdot 0(11 \cdot 6-14 \cdot 7)$ & $12 \cdot 9(11 \cdot 4-14 \cdot 8)$ & .. \\
\hline Year 1 & $9 \cdot 4(8 \cdot 3-10 \cdot 5)$ & $12 \cdot 4(10 \cdot 7-14 \cdot 6)$ & $<0.001$ \\
\hline Year 2 & $9.6(8.4-10.9)$ & $12 \cdot 5(11 \cdot 0-15 \cdot 0)$ & $<0.001$ \\
\hline Year 3 & $10 \cdot 1(9 \cdot 0-11 \cdot 3)$ & $13 \cdot 4(11 \cdot 5-15 \cdot 2)$ & $<0.001$ \\
\hline \multicolumn{4}{|c|}{$\begin{array}{l}\text { Data are median (IQR). At the time of our study folic acid fortification of foods was prohibited in the Netherlands. } \\
\text { p values based on non-parametric tests. *At baseline, data available for } 405 \text { participants in folic acid group and } \\
413 \text { participants in placebo group. At Year } 1 \text {, data available for } 397 \text { participants in folic acid group and } 407 \text { participants in } \\
\text { placebo group. At Year 2, data available for } 389 \text { participants in folic acid group and } 403 \text { participants in placebo group. At } \\
\text { Year } 3 \text {, data available for } 394 \text { participants in folic acid group and } 406 \text { participants in placebo group. †At baseline, data } \\
\text { available for } 405 \text { participants in folic acid group } 413 \text { participants in placebo group. At Year } 3 \text {, data available for } \\
394 \text { participants in folic acid group and } 406 \text { participants in placebo group. } ¥ \text { At baseline, data available for } \\
405 \text { participants in folic acid group and } 413 \text { participants in placebo group. At Year } 3 \text {, data available for } 394 \text { participants in } \\
\text { folic acid group and } 408 \text { participants in placebo group. SAt baseline, data available for } 405 \text { participants in folic acid } \\
\text { group and } 412 \text { participants in placebo group. At Year } 1 \text {, data available for } 397 \text { participants in folic acid group and } \\
404 \text { participants in placebo group. At Year } 2 \text {, data available for } 390 \text { participants in folic acid group and } 404 \text { participants in } \\
\text { placebo group. At Year 3, data available for } 393 \text { participants in folic acid group and } 406 \text { participants in placebo group. }\end{array}$} \\
\hline
\end{tabular}

\begin{tabular}{|c|c|c|}
\hline & Folic acid $(n=405)$ & Placebo $(n=413)$ \\
\hline \multicolumn{3}{|l|}{ Word learning test } \\
\hline Total of three immediate recall trials (number of words) & $26 \cdot 9(5 \cdot 9)$ & $26 \cdot 8(5 \cdot 4)$ \\
\hline Maximum of three immediate recall trials (number of words) & $11 \cdot 2(2 \cdot 2)$ & $11 \cdot 2(2 \cdot 0)$ \\
\hline Delayed recall (number of words) & $8 \cdot 9(2.8)$ & $9.0(2 \cdot 7)$ \\
\hline \multicolumn{3}{|l|}{ Concept shifting test } \\
\hline $\operatorname{Empty}(\mathrm{s})^{*}$ & $5 \cdot 37(1 \cdot 16)$ & $5.43(1.28)$ \\
\hline Numbers (s) & $23 \cdot 26(5 \cdot 82)$ & $23 \cdot 40(6 \cdot 07)$ \\
\hline Letters $(s) \dagger$ & $27 \cdot 01(7 \cdot 40)$ & $27 \cdot 46(9 \cdot 51)$ \\
\hline Numbers and letters $(\mathrm{s}) \ddagger$ & $35 \cdot 95(12 \cdot 28)$ & $36 \cdot 34(13 \cdot 35)$ \\
\hline \multicolumn{3}{|l|}{ Stroop colour-word test } \\
\hline Word reading $(s)^{*}$ & $16 \cdot 34(2 \cdot 75)$ & $16 \cdot 38(3.09)$ \\
\hline Naming colour of ink (s) $s$ & $42.62(10.65)$ & $43.68(11.79)$ \\
\hline Letter digit substitution test, number of digits in $90 \mathrm{~s} \boldsymbol{\Phi}$ & $48.86(8.96)$ & $48.24(8.99)$ \\
\hline Verbal fluency test, number of words & $24 \cdot 8(6 \cdot 3)$ & $24 \cdot 1(5 \cdot 7)$ \\
\hline \multicolumn{3}{|c|}{$\begin{array}{l}\text { Performance did not differ between two groups. }{ }^{*} \text { Data available for } 412 \text { participants in placebo group. †Data availabl } \\
\text { for } 403 \text { participants in folic acid group and } 411 \text { participants in placebo group. } \neq \text { Data available for } 409 \text { participants in } \\
\text { placebo group. SData available for } 404 \text { participants in folic acid group and } 411 \text { participants in placebo group. }\{\text { Data } \\
\text { available for } 410 \text { participants in placebo group. Data are mean (SD). }\end{array}$} \\
\hline
\end{tabular}

\section{Discussion}

In 818 older adults, daily oral folic acid supplementation for 3 years beneficially affected global cognitive function, and specifically memory, and information processing: functions that are sensitive to ageing. ${ }^{1}$ The decline in memory seen with ageing is generally preceded, and might be affected, by a decline in speed functions. ${ }^{32}$ Nonetheless, folic acid supplementation might beneficially affect both memory and speed simultaneously, since high concentrations of homocysteine have been associated with atrophy of the hippocampus, an area of the brain which is important for memory consolidation. ${ }^{33}$ Complex speed, a domain sensitive to ageing, ${ }^{1}$ was not affected by folic acid supplementation. The effect of folic acid might be restricted to basic aspects of speed and information processing, rather than high order information processing. Word fluency was not affected by folic acid supplementation, perhaps not surprisingly, because encyclopaedic memory is a component of crystallised intelligence that stays relatively intact as one grows older. ${ }^{34}$

Our study might have yielded demonstrable effects of folic acid on cognitive function because we used sensitive tests that exist in parallel versions. We also improved the robustness of the underlying cognitive constructs by clustering raw test scores for several tests in compound performance measures. This procedure decreased variation associated with the individual tests. Finally, clustering of raw tests scores limited our cognitive performance outcomes to five a-priori defined outcomes.

By contrast with other trials, we were able to detect an effect of folic acid on several cognitive functions, for several reasons. First, assuming that high plasma total homocysteine concentrations are a causal risk factor for cognitive decline, we selected a population likely to benefit from folic acid supplementation. Second, we had a fairly large study population and supplemented for quite a long period. Third, although we did not attempt to measure the prevalence of dementia at baseline nor its incidence during the duration of the trial, our population is unlikely to have included many cognitively impaired or demented participants, since the general performance on a dementia screening test such as the Mini-Mental State Examination was high, both at the beginning and end of the study. That treatment with folic acid or other B vitamins might feasibly be too late in populations with mild cognitive impairment and dementia. Finally, sensitive tests such as our own-not the commonly used Mini-Mental State Examination, which is a dementia screening device-were needed to detect the subtle effects of B vitamins on cognitive ageing. Importantly, given the general scarcity of positive findings from other trials (table 1) and the multiple comparisons made in our trial, our results need to be confirmed by other investigators to ascertain whether the significant positive effects of folic acid on cognitive performance were due to type 1 error.

A strength of our study is the low attrition rate; a high attrition rate might have biased our findings of cognitive change, since participants with poor cognitive function are likely to withdraw from studies. ${ }^{35}$ In our study, the 12 participants in the folic acid group and five participants in the placebo group who did not return for the end measurements had low scores only on baseline tests of 


\begin{tabular}{|c|c|c|c|c|c|c|c|c|c|c|}
\hline & \multicolumn{4}{|c|}{ Folic $\operatorname{acid}(n=405)$} & \multicolumn{4}{|l|}{ Placebo $(n=413)$} & \multicolumn{2}{|l|}{ Folic acid vs placebo } \\
\hline & Year 0 & Year 3 & $\begin{array}{l}\text { 3-year change in } \\
\text { cognitive } \\
\text { performance, }\end{array}$ & $\mathrm{p}^{*}$ & Year 0 & Year 3 & $\begin{array}{l}\text { 3-year change in } \\
\text { cognitive } \\
\text { performance, } \\
\text { mean (SD) }\end{array}$ & $p^{*}$ & $\begin{array}{l}\text { Cognitive change } \\
\text { attributed to folic acid, } \\
\text { mean difference }(95 \% \mathrm{Cl})\end{array}$ & $\mathrm{p} \dagger$ \\
\hline $\begin{array}{l}\text { Global cognitive function, } \\
\text { mean (SD) Z score }\end{array}$ & $0.006(0.673)$ & $0.073(0.694)$ & $0.067(0.338)$ & $<0.0001$ & $-0.048(0.672)$ & $-0.031(0.701)$ & $0.017(0.332)$ & 0.287 & $0.050(0.004$ to 0.096$)$ & 0.033 \\
\hline $\begin{array}{l}\text { Memory, mean (SD) } \\
\text { Zscore }\end{array}$ & $-0.207(0.959)$ & $0.273(0.965)$ & $0.480(0.724)$ & $<0.0001$ & $-0.206(0.883)$ & $0.142(0.961)$ & $0.348(0.737)$ & $<0.0001$ & $0.132(0.032$ to 0.233$)$ & 0.010 \\
\hline $\begin{array}{l}\text { Sensorimotor speed, } \\
\text { mean (SD) Z score }\end{array}$ & $0.054(0.706)$ & $0.011(0.753)$ & $-0.042(0.458)$ & 0.063 & $0.019(0.836)$ & $-0.087(0.819)$ & $-0.106(0.490)$ & $<0.0001$ & $0.064(-0.001$ to 0.129$)$ & 0.055 \\
\hline $\begin{array}{l}\text { Complex speed, mean } \\
\text { (SD) Z score }\end{array}$ & $0.053(0.803)$ & $0.026(0.868)$ & $-0.027(0.651)$ & 0.405 & $-0.008(0.879)$ & $-0.072(0.865)$ & $-0.064(0.593)$ & 0.029 & $0.037(-0.049$ to 0.122$)$ & 0.40 \\
\hline $\begin{array}{l}\text { Information processing } \\
\text { speed, Z score }\end{array}$ & $0.093(1.008)$ & $0.021(0.967)$ & $-0.072(0.513)$ & 0.005 & $0.024(1.008)$ & $-0.135(1.008)$ & $-0.159(0.517)$ & $<0.0001$ & 0.087 (0.016 to 0.158$)$ & 0.016 \\
\hline $\begin{array}{l}\text { Word fluency, mean (SD) } \\
\text { Z score }\end{array}$ & $0.038(1.056)$ & $0.036(1.029)$ & $-0.002(0.864)$ & 0.961 & $-0.070(0.959)$ & $-0.002(0.953)$ & $0.068(0.859)$ & 0.108 & $-0.070(-0.188$ to 0.048$)$ & $0 \cdot 245$ \\
\hline
\end{tabular}

memory $(0 \cdot 558 Z$ score, 95\% CI $0 \cdot 116-1 \cdot 000)$. Their absence from year-3 tests is unlikely to have affected our estimates for several reasons: the effect of folic acid supplementation on memory was not dependent on baseline performance on the memory tests (data not shown), the number of participants lost to follow-up was minimal, and the effect estimates based on participants with follow-up data were similar to the intention-to-treat analyses. A second strength was the standardised test conditions that reduced variation due to factors such as caffeine and varying breakfasts. ${ }^{36}$

Our study also had some limitations. First, we studied participants with high plasma total homocysteine concentrations: 3044 out of 4200 participants were excluded from the study because of low plasma total homocysteine concentrations. Thus, the effect of folic acid supplementation on cognitive function might be greater than would be expected in populations with lower plasma total homocysteine concentrations-eg, in countries such as the USA, with mandated fortification of flour with folic acid. Second, our findings pertain only to vitamin B12-replete individuals. Suggestions have been made that folic acid supplementation exacerbates neurological symptoms in people with vitamin $B_{12}$ deficiency. ${ }^{37}$ The possibility of folic-acid-mediated exacerbation of neuropathological disorders in people with low concentrations of vitamin $B_{12}$ needs to be addressed by studies that monitor both vitamin $B_{12}$ status and neurological function. As an improvement to our own study, transcobalamin in addition to vitamin $B_{12}$, should be measured, because transcobalamin is a better marker of vitamin $B_{12}$ status than is vitamin $B_{12}$ itself.

Will folic acid supplementation lead to a reduced incidence of dementia? Whereas some have argued that cognitive decline is the beginning of a continuum leading to dementia, ${ }^{38}$ others have argued that the cause of agerelated cognitive decline differs from that of dementia ${ }^{39}$ and that age-related cognitive decline is not an early state of mild cognitive impairment or dementia. ${ }^{2}$ Cognitive tests differ in their ability to identify individuals who worsen to more advanced states such as mild cognitive impairment or dementia. Of our test battery, memory is the most clinically relevant domain. Memory can be used to distinguish between cognitively normal and cognitively impaired people. ${ }^{2}$ Memory storage (delayed recall), in particular, can distinguish between people with nonprogressive mild cognitive impairment and preclinical Alzheimer's disease. ${ }^{40}$ Although folic acid improved performance on tests of memory, including delayed recall, additional research is needed to determine whether folic acid supplementation can reduce the risk of mild cognitive impairment or Alzheimer's disease.

We have shown that 3-year folic acid supplementation improves performance on tests that measure informationprocessing speed and memory, domains that are known to decline with age, in older adults with raised total homocysteine concentrations. Randomised, controlled trials are underway to examine the effect of homocysteinelowering on recurrent vascular disease and cognitive function assessed by the Mini-Mental State Examination or modifications thereof; these and other homocysteinelowering trials should include sensitive measures of cognitive function. Additionally, trials similar to our own should be repeated in other populations to provide greater insight into the clinical relevance of folic acid supplementation, such as in populations with mild cognitive impairment and dementia.

\section{Contributors}

All authors participated in the study design, study implementation, and in the interpretation of the results.

\section{Conflict of interest statement}

Jane Durga currently works at Nestle Research Center in Lausanne, Switzerland and Petra Verhoef currently works at the Unilever Food and Health Research Institute in Vlaardingen, the Netherlands. The work at both food companies entails examining the health benefits of a variety of 
food ingredients, including folic acid. However, the study reported in the current manuscript was completed and submitted to The Lancet before the authors joined the companies, when they were still employed by Wageningen University and Wageningen Centre for Food Sciences. All authors declare that they have no conflict of interest.

\section{Acknowledgments}

We thank all study participants for their time and motivation; the FACIT trial research team for their dedication and enthusiasm; and Dick Willems (Maastricht University, Netherlands) for data verification. The research was funded by a grant from the Netherlands Organisation for Health Research and Development (ZonMw, grant number 20010002), Wageningen University, and Wageningen Centre for Food Sciences. Wageningen Centre for Food Sciences is an alliance of major Dutch food industries, research institutes and the Dutch government. Wageningen Centre for Food Sciences does long-term strategic research for the development of new and innovated food with attention to health aspects.

References

1 van Boxtel MPJ, Buntix F, Houx PJ, Metsemaker JF, Knottnerus A, Jolles J. The relation between morbidity and cognitive performance in a normal aging population. J Gerontol A Biol Sci Med Sci 1998; 53 : M147-54.

2 Lövdén M, Bergman L, Adolfsson R, Lindenberger U, Nilsson L-G. Studying individual aging in an international context: typical pathos of age-related, dementia-related, and mortality-related cognitive development in old age. Psych. Aging 2005; 20: 303-16.

3 Petersen RC, Smith GE, Waring SC, Ivnik RJ, Tangalos EG, Kokmen E. Mild cognitive impairment: clinical characterization and outcome. Arch Neurol 1999; 56: 303-08.

4 Fillit HM, Butler RN, O'Connell AW, et al. Achieving and maintaining cognitive vitality with aging. Mayo Clin Proc 2002; 77: 681-96.

5 Calvaresi E, Bryan J. B vitamins, cognition, and aging: a review. J Geronto. B Psychol Sci Soc Sci 2001; 56: 327-39.

6 Mattson MP, Shea TB. Folate and homocysteine metabolism in neural plasticity and neurodegenerative disorders. Trends Neurosci 2003; 26: 137-46

7 Morris MC, Evans DA, Bienias JL, et al. Dietary folate and vitamin B12 intake and cognitive decline among community-dwelling older persons. Arch Neurol 2005; 62: 641-45.

8 Malouf M, Grimley EJ, Areosa SA. Folic acid with or without vitamin B12 for cognition and dementia. Cochrane Database Sys Rev 2003; 4: CD004514

9 Folstein MF, Folstein SE, McHugh PR. "Mini-mental state". A practical method for grading the cognitive state of patients for the clinician. J Psychiatr Res 1975; 12: 189-98.

10 Fioravanti M, Ferrario E, Massaia M, et al. Low folate levels in the cognitive decline of elderly patients and the efficacy of folate as a treatment for improving memory deficits. Arch Gerontol Geriatr 1997; 26: $1-13$

11 Sommer BR, Hoff AL, Costa M. Folic acid supplementation in dementia: a preliminary report. J Geriatr Psychiatry Neurol 2003; 16: 156-59.

12 Eussen SJ, de Groot LC, Joosten LW, et al. Effect of oral vitamin B-12 with or without folic acid on cognitive function in older people with mild vitamin B-12 deficiency: a randomized, placebo-controlled trial. Am J Clin Nutr 2006; 84: 361-70.

13 McMahon JA, Green TI, Skeaff CM, Knight RG, Mann JI, Williams SM. A controlled trial of homocysteine lowering and cognitive performance. N Engl J Med 2006; 354: 276472.

14 Stott DJ, MacIntosh G, Lowe GD, et al. Randomized controlled trial of homocysteine-lowering vitamin treatment in elderly patients with vascular disease. Am J Clin Nutr 2005; 82: 1320-26.

15 Bryan J, Calvaresi E, Hughes D. Short-term folate, vitamin B-12 or vitamin B-6 supplementation slightly affects memory performance but not mood in women of various ages. J Nutr 2002; 132: 1345-56.

16 Toole JF, Malinow MR, Chambless LE, et al. Lowering homocysteine in patients with ischemic stroke to prevent recurrent stroke, myocardial infarction, and death: the Vitamin Intervention for Stroke Prevention (VISP) randomized controlled trial. JAMA 2004; 291: 565-75.

17 Clarke R, Harrison G, Richards S, on behalf of the VITAL Trial Collaborative Group. Effect of vitamins and aspirin on markers of platelet activation, oxidative stress and homocysteine in people at high risk of dementia. J Intern Med 2003; 254: 67-75.
18 Lewerin C, Matousek M, Steen G, Johansson B, Steen B, Nilsson-Ehle $\mathrm{H}$. Significant correlations of plasma homocysteine and serum methylmalonic acid with movement and cognitive performance in elderly subjects but no improvement from short-term vitamin therapy: a placebo-controlled randomized study. Am J Clin Nutr 2005; 81: $1155-52$.

19 Obied R. Effect of the B-vitamins on cognitive function in elderly people with mild cognitive dysfunction [abstract]. Clin Chem Lab Med 2005; 43: A28.

20 Refsum H, Smith AD, Ueland PM, et al. Facts and recommendations about total homocysteine determinations: an expert opinion. Clin Chem 2004; 50: 3-32.

21 Jolles J, Houx PJ, van Boxtel MPJ, Ponds RWHM. The Maastricht aging study: determinants of cognitive aging. Maastricht: Neuropsych Publishers, 1995. http://www.np.unimaas.nl/maas/moreinfo/MAAS PB_intro.pdf (accessed Dec 4, 2006).

22 Durga J, van Boxtel MP, Schouten EG, Bots ML, Kok FJ, Verhoef P. Folate and the methylenetetrahydrofolate reductase $677 \mathrm{C}-->\mathrm{T}$ mutation correlate with cognitive performance. Neurobiol Aging 2006; 27: $334-43$.

23 van der Elst W, van Boxtel MP, van Breukelen GJ, Jolles J. Rey's verbal learning test: normative data for 1855 healthy participants ages 24-81 years and the influence of age, sex, education, and mode of presentation. J Int Neuropsychol Soc 2005; 11: 290-301.

24 van der Elst W, van Boxtel MP, van Breukelen GJ, Jolles J. The Concept Shifting Test: adult noramtuive data. Psychol Assess 2006; 18: 424-32.

25 van der Elst W, van Boxtel MP, van Breukelen GJ, Jolles J The Stroop Color-word Test: influence of age, sex, and education; and normative data for a large sample across the adult range. Assessment 2006; 13: 62-79.

26 van der Elst W, van Boxtel MP, van Breukelen GJ, Jolles J. The Letter Digit Substitution Test: normative data for 1858 healthy participants aged 24-81 years from the Maastricht Aging Study: influence of age, education and sex. J Clin Exp Neuropsychol 2006; 28: 998-1009.

27 van der Elst W, van Boxtel MP, van Breukelen GJ, Jolles J. Normative data for the animal, profession and letter $\mathrm{M}$ naming verbal fluency tests for Dutch speaking participants and the effets of age, education, and sex. J Int Neuropsych Soc 2006; 12: 80-89.

28 Frosst P, Blom HJ, Milos R, et al. A candidate genetic risk factor for vascular disease: a common mutation in methylenetetrahydrofolate reductase. Nat Genet 1995; 10: 111-13.

29 De Bie SE. Standard questions 1987: proposal for uniformization of questions regarding background variables and interviews [in Dutch]. Leiden: Leiden University Press, 1987.

30 Kalmijn S, van Boxtel MP, Ocke M, Verschuren WM, Kromhout D, Launer LJ. Dietary intake of fatty acids and fish in relation to cognitive performance at middle age. Neurology 2004: 62: 275-80.

31 Scarmeas N, AlbertSM, Manly JJ, Stern Y. Education and rates of cognitive decline in incident Alzheimer's disease. J Neurol Neurosurg Psychiatry 2006; 77: 308-16.

32 Salthouse TA. The processing-speed theory of adult age differences in cognition. Psychol Rev 1996; 103: 403-28.

33 den Heijer T, Vermeer SE, Clarke R, et al. Homocysteine and brain atrophy on MRI of non-demented elderly. Brain 2003; 126: 170-75.

34 Horn JL, Cattell RB. Age differences in fluid and crystallized intelligence. Acta Psychol 1967; 26: 107-29.

33 Cooney TM, Schaie KW, Willis SL. The relationship between prior functioning on cognitive and personality dimensions and subject attrition in longitudinal research. J Gerontol 19881; 43: 12-17.

36 Kaplan RJ, Greenwood CE, Winocur G, Wolever TM. Dietary protein, carbohydrate, and fat enhance memory performance in the healthy elderly. Am J Clin Nutr 2001; 74: 687-93.

37 Campbell NRC. How safe are folic acid supplements? Arch Intern Med 1996; 156: 1638-44.

38 Brayne C, Calloway P. Normal ageing, impaired cognitive function, and senile dementia of the Alzheimer's type: a continuum? Lancet 1988; 331: 1265-67.

39 Morrison JH, Hof PR. Life and death of neurons in the aging brain. Science 1997; 278: 412-19.

40 Visser PJ, Verhey FR, Ponds RW, Jolles J. Diagnosis of preclinical Alzheimer's disease in a clinical setting. Int Psychogeriatr 2001; 13 411-23. 